\title{
O POTRZEBIE KSZTAŁCENIA TECHNICZNEGO W ODBUDOWIE NIEPODLEGŁEJ POLSKI W PRZEKAZIE „PRZEGLĄDU TECHNICZNEGO” Z LAT 1914-1918
}

\begin{abstract}
Michalski Grzegorz, O potrzebie ksztatcenia technicznego w odbudowie niepodległej Polski w przekazie "Przegladu Technicznego" z lat 1914-1918 [About the Need of Technical Education During the Period of Reconstruction of Independent Poland in the Message of Przeglad Techniczny from 19141918]. Studia Edukacyjne nr 53, 2019, Poznań 2019, pp. 41-57. Adam Mickiewicz University Press. ISSN 1233-6688. DOI: 10.14746/se.2019.53.3

After the outbreak of the Great War, a discussion on the role of the school system in the reconstruction of the independent Polish state started in the Warsaw-based Stowarzyszenie Techników Polskich (Association of Polish Technicians). The research on the contents of Przeglad Techniczny (Technical Review), which was a magazine published by that organization, shows that the editors saw the relationship between professional education and industrial development of the state, free from restrictions imposed by the invaders, and, as a result, published notes and articles to convince the society about the need to educate teenagers in occupational schools. Thus, they informed the readers on the operation of schools of that type and various initiatives and forms of technical education and improvement, most of all in Warsaw. They also presented their own projects in that area. Supporting the organization of the technical education system, they proposed three-year lower occupational schools for professional education of workmen, secondary schools educating "intelligent technicians adapted to the needs of the industry", and higher technical schools conferring a title of the engineer on their graduates.
\end{abstract}

Key words: technical magazines, Przeglad Techniczny, Great War, occupational education, popularisation of technical knowledge

Wybuch pierwszej wojny światowej i wyparcie Rosjan z Królestwa Polskiego uformowało całkowicie nową sytuację polityczną. W utworzonych na jego terytorium dwóch strefach okupacyjnych - niemieckiej ze stolicą

${ }^{1}$ Praca naukowa finansowana w ramach programu Ministra Nauki i Szkolnictwa Wyższego pod nazwą "Szlakami Polski Niepodległej” w latach 2018-2023; nr projektu: 01SPN 170020 18; kwota finansowania 751222 zł. 
w Warszawie i austriackiej ze stolicą w Lublinie - częściowo spolonizowano administrację, umożliwiając powstawanie i działanie instytucji samorządowych, w znacznym stopniu spolszczono także sądownictwo, honorowano prawo do manifestowania postaw patriotycznych oraz usunięto większość formalnych przeszkód do pełnego unarodowienia szkolnictwa wszystkich szczebli i typów ${ }^{2}$. Stworzenie przez nowych najeźdźców o wiele bardziej liberalnych warunków umożliwiających Polakom legalną działalność na niwie oświatowej wpłynęło na niespotykaną wcześniej skalę aktywności w tej dziedzinie, która zmierzała do trwałego usunięcia negatywnych następstw polityki rusyfikacyjnej. Dlatego, z jednej strony niestrudzenie dążono do pełnego podporządkowania szkolnictwa polskim władzom samorządowym oraz zintensyfikowano walkę $\mathrm{z}$ analfabetyzmem poprzez organizowanie różnych form edukacji na poziomie początkowym, zarówno w miastach, jak i na $\mathrm{wsi}^{3}$, z drugiej natomiast strony - podjęto wiele prac koncepcyjnych dotyczących przyszłości oświaty w niepodległej Polsce ${ }^{4}$. Warto w tym miejscu zauważyć, że choć główną rolę w tym zakresie odgrywały zrzeszenia nauczycielskie $^{5}$, które prezentowały propozycje dotyczące przede wszystkim organizacji szkolnictwa i miejsca w niej szkoły najniższego stopnia, a także podstaw i zasad kształcenia nauczycieli, to jednak nie tylko one wypowiadały się wówczas na ten temat. Spośród innych organizacji, przedstawiających swój punkt widzenia na sprawy oświaty w wolnej już od zaborców Polski, szczególnie wyróżniało się Stowarzyszenie Techników Polskich ${ }^{6}$, które na

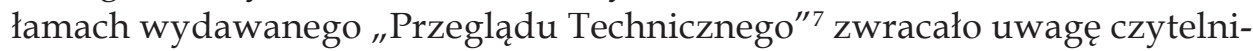

2 A. Chwalba, Samobójstwo Europy. Wielka Wojna 1914-1918, Kraków 2014 s. 595; M. Korzeniowski, Wojna na Lubelszczyźnie w latach 1914-1915 w świetle wspomnień, Przegląd Wschodnioeuropejski, 2017, VIII, 2, s. 11-21.

${ }_{3}^{3}$ R. Wroczyński, Dzieje oświaty polskiej 1795-1945, Warszawa 1987, s. 275-276.

${ }^{4}$ F.W. Araszkiewicz, Szkoła średnia ogólnoksztatcąca na ziemiach polskich w latach 1915-1918, Rozprawy z Dziejów Oświaty, 1967, 10, s. 175.

${ }^{5}$ Od 1905 r. w Królestwie Polskim działały dwie organizacje nauczycielskie: Polski Związek Nauczycielski i Stowarzyszenie Nauczycielstwa Polskiego. W 1917 r. połączyły się one w jeden związek, który przyjął nazwę Stowarzyszenie Nauczycielstwa Polskiego. Zob. P. Sosnowski, Dzieje Stowarzyszenia Nauczycielstwa Polskiego (1905-1919), Warszawa 1930; M. Szulkin, Polski Związek Nauczycielski (1905-1917). Studium z dziejów postępowego ruchu nauczycielskiego w Polsce, Warszawa 1968; F. Filipowicz, Narodziny ruchu, [w:] Związek Nauczycielstwa Polskiego. Zarys dziejów 1905-1985, red. B. Grześ, Warszawa 1986, s. 76-97.

${ }^{6}$ Stowarzyszenie to powstało w 1898 r. z inicjatywy osób skupionych wcześniej w Sekcji Technicznej oddziału warszawskiego Towarzystwa Popierania Rosyjskiego Przemysłu i Handlu.

7 Inicjatorem wydawania „Przeglądu Technicznego” był inż. Paweł Kaczyński (1799-1878). Po ukazaniu się w 1866 r. kilku numerów, zawiesił on dalszą jego edycję ze względu na brak dostatecznych środków finansowych. W 1875 r. czasopismo to ponownie wprowadził na rynek księgarski inż. Stefan Kossuth (1849-1919), zachowując w pełni wypracowany wcześniej przez inż. Feliksa Kucharzewskiego (1849-1935) charakter i profil tego periodyku, któremu przypisał zadanie podnoszenia poziomu kultury technicznej, popularyzowania innowacji technicznych, zapoznawania $\mathrm{z}$ nowymi rozwiązaniami technologicznymi $\mathrm{w}$ przemyśle, a także 
ków na potrzebę umasowienia wykształcenia ogólnego oraz uświadamiało o konieczności zmiany nastawienia do kształcenia profesjonalnego ${ }^{8}$, ponieważ nie było ono nigdy doceniane przez społeczeństwo, natomiast niski poziom kultury technicznej stanowił przeszkodę ograniczającą postęp technologiczny ${ }^{9}$, od którego zależał rozwój nowoczesnego państwa i znaczenie, jakie posiadało ono na arenie międzynarodowej. Zastanawiając się nad kompleksowym programem gospodarczym dla nowej Polski i możliwościami jego praktycznego wdrożenia w skomplikowanych uwarunkowaniach pozaborowych, pisano:

Dla uzupełnienia tej charakterystyki należałoby podkreślić jeszcze pewne ujemne objawy życia naszego i innej kategorii, lecz nie mniej związane z kwestyą uprzemysłowienia kraju, a mianowicie: niski stan szkolnictwa ogólnego i zawodowego, pewien brak sił fachowych i organizacyjnych, brak przedsiębiorczości, brak „tężyzny ekonomicznej”, brak "ducha kapitalistycznego" i bierność wobec kurczenia się naszego stanu posiadania ${ }^{10}$.

Stojąc na stanowisku, że dla przyszłości gospodarczej odrodzonej Polski ważne jest przekonanie społeczeństwa o wartości wykształcenia zawodowego ${ }^{11}$, redaktorzy „Przeglądu Technicznego" wielką wagę przywiązywali do informowania o działalności na terenie Warszawy nielicznych wówczas szkół technicznych. Dokładnie śledząc przebieg kształcenia w Szkole Mechaniczno-Technicznej H. Wawelberga i S. Rotwanda, zauważano, że po wielu latach od jej powstania w 1895 roku $^{12}$ stała się ona wzorcową placówką edukacyjną, która w opinii przemysłowców kształci młodzież na wysokim poziomie, nie ograniczając się wyłącznie do przekazywania najbardziej

szerzenia w społeczeństwie potrzeby i znaczenia oświaty zawodowej. W okresie pierwszej wojny światowej komitetem redakcyjnym kierował inż. Stanisław Manduk (1877-1948). Zob. E. Mańkiewicz-Cudny, 140 lat "Przegladu Technicznego", Rocznik PTHT, 2006, s. 7-18.

${ }^{8}$ Potrzeba uprzemystowienia kraju i ogólne widoki rozwoju przemystu na Ziemiach Polskich, „Przegląd Techniczny” 1915, nr 51 i 52, s. 487-489.

9 Takie samo stanowisko prezentowało „Czasopismo Techniczne”, które było organem Polskiego Towarzystwa Politechnicznego we Lwowie. Zob. J. Piłatowicz, Polskie czasopisma ogólnotechniczne przed $i$ w okresie I wojny światowej, Kwartalnik Historii Prasy Polskiej, 1990, t. 29, nr 3-4, s. 26-27.

${ }^{10}$ Tamże, s. 485.

${ }^{11}$ Zastanawiając się nad przeszkodami utrudniającymi rozwój przemysłowy kraju, wskazywano na kilka palących i wciąż nierozwiązanych kwestii społecznych: robotniczej, mieszkaniowej, kobiecej i oświatowej. Odnosząc się do tej ostatniej, pisano: „Pod tym względem powinien być zwrot $\mathrm{w}$ wychowaniu domowem i społecznem. U nas jest zasada, że gdy chłopiec niechętnie bierze się do książki, wówczas mu się grozi, że pójdzie do szewca, a nie mówi się: ucz się dlatego, bo będziesz pożyteczniejszym członkiem społeczeństwa od tego, który się nie uczył". Potrzeba uprzemystowienia kraju, s. 489.

${ }^{12}$ L. Uzarowicz, Szkoła Wawelberga i Rotwanda, [w:] Politechnika Warszawska 1915-1965, Warszawa 1965, s. 27-36. 
niezbędnej wiedzy teoretycznej, ale dzięki licznym zajęciom warsztatowym i obowiązkowym praktykom wakacyjnym $\mathrm{w}$ odlewniach i działach mechanicznych przedsiębiorstw doskonale przygotowuje do wykonywania zadań na stanowiskach techników i pomocników inżynierów. Podkreślano, że organizowane co jakiś czas pokazy prac ćwiczeniowych uczniów zaświadczały o dużym ich przystosowaniu do oczekiwań zgłaszanych przez fabrykantów. Z kolei, dokonując oceny eksponowanych w tej szkole modeli maszyny parowej i silników spalinowych, wyrażono pogląd, że nie ustępowały one swoją jakością od takich samych urządzeń konstruowanych w uczelniach zagranicznych. Dobre wyniki w tym zakresie przypisywano inżynierowi Leonowi Karasińskiemu ${ }^{13}$, który zapoczątkował wspólne wykonywanie projektów przez grupę złożoną z kilku uczniów, co - zdaniem reporterów - zdecydowanie wpłynęło na sprawność i wydajność działań konstrukcyjnych oraz przyczyniało się do zrozumienia i opanowania potrzebnych w przyszłej działalności zawodowej umiejętności współpracy w zespole. Z uznaniem wypowiadano się o pracach uczniowskich obejmujących całkowite wykonanie maszyn oraz większych i mniejszych zespołów mechanicznych, a także wytworów stolarsko-modelarskich, odlewniczych, kowalskich, zecerskich oraz związanych z obróbką skrawaniem ${ }^{14}$.

$\mathrm{Z}$ adnotacji $\mathrm{w}$ piśmie wynika, że wojenna drożyzna oraz trudności $\mathrm{w}$ zaopatrzeniu w surowce i materiały spowodowały, że w kolejnych latach Szkoła Mechaniczno-Techniczna H. Wawelberga i S. Rotwanda zrezygnowała z wymogu przygotowywania przez uczniów prototypów maszyn i urządzeń, ograniczając się wyłącznie do obowiązku wykonywania przez nich rysunków technicznych, dotyczących między innymi pomiarów mierniczych, części maszyn, wiązarów dachowych, instalacji elektrycznych, kotłów parowych, silników parowych i spalinowych. Przekonywano jednak, że pomimo zmian $\mathrm{w}$ programie zajęć warsztatowych, wymuszonych przez okoliczności zewnętrzne, kierownictwo szkoły dalej nieustannie dążyło - jak to określono - do „postępu w dziedzinie praktyczno-przemysłowego przygotowania swych wychowańców", którzy zajmą po odzyskaniu niepodległości „placówki rodzimego przemysłu”. Jako przykład podawano, że każdy z nich opracowywał nie tylko ogólny rysunek techniczny danej części maszyny, ale precyzyjnie wykreślał również wszystkie jej elementy ${ }^{15}$.

${ }^{13}$ Sylwetki profesorów Politechniki Warszawskiej. Leon Karasiński (1879-1945), oprac. J. Kubiatowski, http:/ / bcpw.bg.pw.edu.pl/Content/842/sylw_prof_027.pdf

${ }_{14}$ Ze Szkoty Mechaniczno-Technicznej Wawelberga i Rotwanda, "Przegląd Techniczny" 1914, nr 31, s. 414.

${ }^{15}$ Ze Szkoty Mechaniczno-Technicznej Wawelberga i Rotwanda, „Przegląd Techniczny” 1916, nr 7-8, s. 58 . 
Wychodząc z założenia, że do odbudowy kraju należy przystąpić jeszcze przed usankcjonowaniem jego statusu jako państwa suwerennego, redaktorzy „Przeglądu Technicznego" wielką wagę przywiązywali do problemu stworzenia ojczystego przemysłu elektrotechnicznego, który w ich przekonaniu nie mógł się swobodnie i w wystarczającym stopniu rozwijać w rozdzielonych kordonami dzielnicach Polski, ponieważ był niemal całkowicie uzależniony od kapitału państw ościennych. Jeden z autorów tak pisał na ten temat:

W Królestwie Polskim przemysł elektrotechniczny prawie że nie istnieje, gdyż przed wojną wytwarzano jedynie: druty żelazne, lampy żarowe, ogniwa galwaniczne, węgle do celów elektrycznych, aparaty telegraficzne i prostsze przyrządy elektryczne ${ }^{16}$.

Wykazując, że ten dział przemysłu stanowi dźwignię nowoczesnej gospodarki, obszernie informowano o inicjatywie Stanisława Śliwińskiego ${ }^{17}$ z Koła Elektrotechników Stowarzyszenia Techników Polskich popularyzowania w Warszawie wiedzy elektrotechnicznej. Popierając tego typu przedsięwzięcia, zauważano, że jego pomysłodawca kierował się słusznym przekonaniem, że coraz większa liczba ludności bezpośrednio korzysta $\mathrm{z}$ oświetlenia elektrycznego, telefonów i maszyn elektrycznych, natomiast niemal zupełnie nie zdaje sobie sprawy z istoty tych urządzeń oraz sposobu ich racjonalnego użytkowania. Zdając sprawozdanie z pierwszego cyklu odczytów, które wygłoszono w marcu 1916 roku, podano do wiadomości, że wśród autorów znaleźli się uznani w środowisku inteligencji technicznej inżynierowie: Marian Grotowski, Jan Tymowski, Edward Potemski, Ksawery Gnoiński, Mieczysław Sikorski oraz wspomniany wcześniej Stanisław Śliwiński, którzy kolejno analizowali problem fizycznych podstaw elektrotechniki, wytwarzania energii elektrycznej i jej wykorzystania w procesach produkcyjnych, różnych aspektów związanych z zagadnieniem światła elektrycznego, a także kwestie zastosowania prądów stałych, szybko zmiennych, promieni rentgenowskich oraz fal elekromagnetycznych. Przechodząc do wniosków z obserwacji przebiegu kilkudniowej serii wykładów, zaznaczono, że należy je kontynuować, ponieważ pomimo braku odpowiedniej reklamy i tak wzbudziły one ogromne zainteresowanie wśród mieszkańców miasta, o czym zaświadczał fakt, że średnio każdy z nich zgromadził około 150 osób, wśród których przede wszystkim przeważała młodzież szkolna. Adresując redakcyjny apel do aktywnych społecznie elektrotechników, napisano: s. 302 .

${ }^{16}$ J. Tymowski, Niższe szkolnictwo elektrotechniczne, „Przegląd Techniczny” 1917, nr 35 i 36,

17 Zob. S.T. Sroka, Śliwiński Stanisław (1875-1950), [w:] Polski Stownik Biograficzny, t. 50/4, Warszawa - Kraków 2016, s. 624-626. 
O ile więc w przyszłym roku Koło przystąpi do zorganizowania nowej seryi odczytów, to ma wszelkie dane do liczenia na powodzenie, bo i temat jest interesujący dla szerszej publiczności i prelegenci wykazali zupełną umiejętność dostosowania swego wykładu do poziomu słuchaczów ${ }^{18}$.

Ale na łamach „Przeglądu Technicznego” nie zawężano przekazu do podejmowanych działań edukacyjnych przez Koło Elektrotechników, ponieważ miały one jedynie za zadanie wywołanie trwałego zaciekawienia i zrozumienia przez ludność wielu problemów z tego obszaru wiedzy. Twórcom pisma bardziej natomiast zależało na rozszerzaniu kręgu osób chcących przygotowywać się do objęcia stanowisk elektrotechników w zakładach przemysłowych. Dlatego przybliżano specyfikę różnych form kształcenia, które przysposabiały w umiejętności praktyczne do tego wciąż mało znanego, lecz wyjątkowo potrzebnego gospodarce zawodu. Przypominano, że z powodu wybuchu wojny Muzeum Przemysłu i Rolnictwa dopiero po dwóch latach ${ }^{19}$ wznowiło w Warszawie specjalny kurs dla monterów urządzeń elektrycznych ${ }^{20}$. Nazywając je pierwszą polską niższą uczelnią elektrotechniczną, szczegółowo przedstawiono wykaz obowiązkowych zajęć z przypadającą im liczbą godzin oraz z podziałem na każdy z dwóch semestrów. Omawiając program nauczania, dokładnie scharakteryzowano składające się na niego następujące przedmioty: rysunek techniczny, maszynoznawstwo, elektrotechnikę, prądy słabe, budowę sieci elektrycznych, instalacje elektryczne oraz ćwiczenia praktyczne w pracowni wyposażonej w motor trójfazowy sprzężony z dynamomaszyną prądu stałego, zespół urządzeń złożony z motoru prądu zmiennego, dynamomaszynę prądu stałego i prądnicę prądu zmiennego, kilka mniejszych silników prądu stałego i zmiennego, kilka lamp łukowych, wiele przyrządów

${ }^{18}$ K. M., Popularyzacya wiedzy elektrotechnicznej. Odczyty popularne w Warszawie, „Przegląd Techniczny" 1916, nr 17 i 18, s. 177.

${ }^{19}$ Kursy te powołano do życia w Warszawie w 1908 r. Rokrocznie zapisywało się na nie około 120. osób. Do wybuchu pierwszej wojny światowej ich program obejmował wysłuchanie wykładów z przedmiotów: elektrotechnika, budowa maszyn elektrycznych, obliczanie długości przewodników i ich montaż, telefony, telegrafia i sygnalizacja oraz rysunek techniczny oraz udział $\mathrm{w}$ zajęciach praktycznych $\mathrm{w}$ odpowiednio wyposażonych pracowniach. Zob. J. T-i, Kursa wieczorowe dla elektromonterów przy Muzeum Przemystu i rolnictwa, „Przegląd Techniczny" 1916, nr 47 i 48, s. 454; J. Tymowski, Niższe szkolnictwo, s. 302. Por. też: J. Miąso, Szkolnictwo zawodowe w Królestwie Polskim w latach 1815-1915, Wrocław - Warszawa - Kraków 1966, s. 276.

${ }^{20}$ Warto zauważyć, że dla osób nieposiadających żadnej wiedzy z nauk ścisłych, ale potrafiących czytać i pisać po polsku, Muzeum Przemysłu i Rolnictwa zorganizowało chcącym zdobyć kwalifikacje montera urządzeń elektrycznych wieczorowy kurs przygotowawczy, który trwał dziewięć miesięcy. Na jego program składały się każdego tygodnia wykłady z następujących przedmiotów: geometria i rysunek geometryczny (4 godz.), arytmetyka i algebra (3 godz.), fizyka (2 godz.), chemia (1 godz.), ćwiczenia w pracowni fizycznej ( 2 godz.), ćwiczenia w pracowni chemicznej (2 godz.). Zob. J. T-i, Kursa przygotowawcze dla elektromonterów przy Muzeum Przemystu i Rolnictwa, „Przegląd Techniczny” 1917, nr 43 i 44, s. 366. 
mierniczych i małą baterię akumulatorów. Odnosząc się do oprzyrządowania warsztatu, wyrażono pogląd:

Tak urządzona pracownia umożliwia prowadzenie ćwiczeń o dość szerokim zakresie, bo oprócz zasadniczych pomiarów uczniowie wykonywują badania maszyn, przyłączanie równoległe prądnicy prądu zmiennego do sieci, puszczanie w ruch silnika synchronicznego i.t. $\mathrm{p}^{21}$.

Warto w tym miejscu zauważyć, że rekomendując kształcenie na kursach dla monterów urządzeń elektrotechnicznych, redakcja pisma łłumaczyła, że po ich ukończeniu słuchacz musiał przystąpić do egzaminów, natomiast jeśli zdecydował się dodatkowo do odbycia jeszcze trzyletniej praktyki i złożenia po niej specjalnego egzaminu, na którym należało wykazać się dokładną znajomością przepisów bezpieczeństwa oraz wykonać projekt niewielkiego urządzenia elektrycznego, otrzymywał on na mocy uchwały Magistratu miasta stołecznego Warszawy certyfikowane prawo do wykonywania instalacji elektrycznych przyłączanych do sieci miejskiej ${ }^{22}$.

W „Przeglądzie Technicznym” zachęcano także do udziału w szkoleniach na monterów w innych rejonach Królestwa Polskiego. Pisano, że podobną do warszawskiej „uczelni” były wzorowo zorganizowane w tym zakresie kursy w Sosnowcu, które powstały w marcu 1915 roku z inicjatywy działającego w tym mieście Koła Elektrotechników przy Stowarzyszeniu Techników. Informowano, że składały się na nie dwa cykle kształcenia: przygotowawczy i stricte zawodowy. Od kandydatów na pierwszy z nich oczekiwano praktyki monterskiej, jednak aby nie ograniczać dostępu do edukacji, nie kładziono na ten wymóg silnego nacisku i przyjmowano wszystkie osoby, które posiadały jedynie umiejętność czytania i pisania po polsku. Kurs ten trwał sześć i pół miesiąca i miał na celu przekazanie - jak to określono - podstawowych wiadomości z nauk pomocniczych, czyli języka polskiego (42 godz.), arytmetyki i algebry (126 godz.), geometrii i rysunku geometrycznego (56 godz.), fizyki i chemii (126 godz.) oraz rysunku technicznego (70 godz.). Z kolei drugi, ośmiomiesięczny kurs miał już specjalistyczny charakter i obejmował wykłady z następujących przedmiotów: maszyny elektryczne (105 godz.), oświetlenie (56 godz.), budowa linii elektrycznych (50 godz.), miernictwo elektryczne (35 godz.), urządzenia wysokiego napięcia (20 godz.), prądy słabe (20 godz.),

${ }^{21}$ J. Tymowski, Niższe szkolnictwo, s. 303.

22 Podczas naboru na pierwszy kurs, który ogłoszono po dwuletniej przerwie, zgłosiło się 161 kandydatów, przyjęto 77., a po zdaniu egzaminów świadectwo kończenia otrzymało 48. słuchaczy. W 1917 r. odbyły się po raz pierwszy egzaminy na prawo prowadzenia robót instalacyjnych w Warszawie, które z pomyślnym wynikiem złożyły tylko dwie osoby. Zob. J. Tymowski, Niższe szkolnictwo, s. 303. 
przepisy bezpieczeństwa (20 godz.), silniki mechaniczne (30 godz.), a także rysunki techniczne $(84 \text { godz. })^{23}$.

Odwołując się do danych statystycznych, z których wynikało, że już przed wojną tylko w samym Królestwie Polskim funkcjonowało 25 elektrowni publicznych, natomiast w czasie wojny, wskutek braku nafty, powstało jeszcze dodatkowo przeszło 75 małych wytwórni prądu, publicyści „Przeglądu Technicznego" postawili tezę, że po wyzwoleniu Polski spod administracji zaborczej i odbudowywaniu zniszczonych przez działania zbrojne zakładów przemysłowych, w tym niemal kompletnie wymagających napraw większości elektrowni fabrycznych, wzrośnie skokowo zapotrzebowanie na elektrotechników. Podkreślano:

W tych warunkach potrzeba i znaczenie szkolnictwa zawodowego jest jasna, w razie zaś zaniedbania tej dziedziny stanowiska w przemyśle zajmą obcokrajowcy, a do tego nie powinniśmy dopuścić ${ }^{24}$.

Nie wyrażając więc zgody na sprowadzanie wykształconych kadr z zagranicy, wysunięto postulat, aby w pierwszych latach niepodległości skoncentrować kształcenie elektromonterów na kursach wieczorowych, funkcjonujących nie jak dotąd tylko w Warszawie i Sosnowcu, ale także w Łodzi i Częstochowie. Podpowiadano, że ze względu na niski poziom szkolnictwa ludowego należy w tym przypadku od kandydatów wymagać wyłącznie umiejętności czytania i pisania oraz udokumentowania doświadczeń zawodowych. Dowodzono:

Jeżeli warunki przyjęcia co do wykształcenia będą surowsze, to będziemy mieli to, co jest w Warszawie: na kursa monterskie przy Muzeum Przemysłu i Rolnictwa rok rocznie zgłasza się bardzo mała liczba kandydatów, bo zaledwie 15-20, gdy tymczasem w samej tylko Warszawie monterów i pomocników bez żadnego wykształcenia specyalnego jest około 500; cóż kiedy wymaga się od nich uczęszczania w ciągu trzech lat do klas rzemieślniczo-przemysłowych, a tem samem utrudnia im korzystanie ze wzorowo urządzonej szkoły ${ }^{25}$.

Z kolei, ustosunkowując się do konstrukcji planu nauczania, uważano, że wykłady z zakresu przedmiotów specjalistycznych należy poprzedzić oddziałem przygotowawczym, którego program odpowiadałby pozytywnie już zweryfikowanemu programowi kursów monterskich realizowanych w Sosnowcu. Jednocześnie podkreślano, że zarówno w ramach jednego, jak i dru-

${ }^{23}$ Kursa dla monterów elektrotechników w Sosnowcu, „Przegląd Techniczny” 1916, nr 17 i 18, s. 177.

${ }^{24}$ J. Tymowski, Niższe szkolnictwo, s. 304.

25 Tamże. 
giego bloku kształcenie nie powinno trwać dłużej niż półtora roku, bo w przeciwnym razie tylko mała liczba słuchaczy potrafi wytrwać do jego końca.

Aby ujednolicić i podnieść poziom edukacji instalatorów, opowiadano się za standaryzacją treści programowych wszystkich przeznaczonych dla nich kursów, a także za wprowadzeniem legislacyjnego rozwiązania, zapewniającego osobom, które je ukończą i następnie odbędą trzyletnią praktykę w zawodzie, a także złożą specjalny egzamin, otrzymanie stałego prawa do wykonywania robót przyłączeniowych we wszystkich elektrowniach na terenie całego kraju.

Równolegle z koncepcją kursów dla monterów, na łamach „Przeglądu Technicznego" ogłaszano projekty kształcenia personelu obsługującego elektrownie, tak zwanych maszynistów. Poddając krytyce organizowanie dla nich szkoleń $\mathrm{w}$ ciągu roku szkolnego ${ }^{26}$, które zupełnie nie uwzględniały specyfiki funkcjonowania tych przedsiębiorstw, postulowano ich urządzanie wyłącznie w okresie letnim, ponieważ wówczas, ze względu na dużo mniejsze zapotrzebowanie na energię elektryczną, pracownicy są mniej obciążeni codziennymi zadaniami. Proponowano, aby w tym przypadku zajęcia odbywały się przy już istniejących kursach dla monterów, dzięki czemu z jednej strony lepiej zostaną wykorzystane urządzenia szkolne, z drugiej natomiast - znacznie obniży to koszty ich obsługi administracyjnej i dydaktycznej ${ }^{27}$.

Dostrzegając szybki rozwój elektrotechniki, który wymagał w tamtych latach przygotowania fachowców w coraz węższych specjalizacjach, autorzy czasopisma występowali z propozycjami urządzania krótko trwających szkoleń dla osób obsługujących dźwigi, kinematografy i aparaty elektromedyczne, a także instalujących piorunochrony ${ }^{28}$.

Wykładając czytelnikom „Przeglądu Technicznego” problem warunków, jakie powinny być spełnione, aby zapewnić w okresie pozaborowym

${ }^{26}$ Pierwsze kursy dla maszynistów obsługujących elektrownie, na które składały się zajęcia z zakresu budowy i obsługi urządzeń elektrycznych, kotłów parowych i silników różnych typów zaczęło organizować w 1910 r. Muzeum Przemysłu i Rolnictwa w Warszawie przy funkcjonujących w tej placówce od 1907 r. Klasach Rzemieślniczo-Przemysłowych, przeznaczonych dla młodzieży zatrudnionej w fabrykach lub uczącej się rzemiosła u majstrów. W czasie pierwszej wojny światowej inicjatywę w tym zakresie przejawiało Koło Elektrotechników przy Stowarzyszeniu Techników w Warszawie, które w porozumieniu z zarządem Klas Rzemieślniczo-Przemysłowych ogłaszało rekrutację na tego typu kursy, które odbywały się od 15 kwietnia do 15 czerwca każdego roku. Warunki przyjęcia były następujące: ukończony 18. rok życia, umiejętność czytania i pisania oraz znajomość czterech działań arytmetycznych w zakresie liczb stałych, przynajmniej dwuletnia praktyka elektrotechniczna oraz wniesienie za cały kurs wpisowego w wysokości 60 marek. Na program kształcenia (192 godziny) składały się zajęcia z: arytmetyki (36 godz.), fizyki i chemii (42 godz.), elektrotechniki (36 godz.), obsługi maszyn elektrycznych (24 godz.), maszynoznawstwa (24 godz.) oraz ćwiczenia w pracowni elektrycznej (30 godz.). Zob. Kursa zawodowe dla maszynistóww, „Przegląd Techniczny” 1917, nr 47-48, s. 394.

${ }_{27}$ J. Tymowski, Niższe szkolnictwo, s. 305.

${ }^{28}$ Tamże. 
pomyślny rozwój gospodarczy $\mathrm{kraju}^{29}$, wychodzono z założenia, że do najważniejszych należało - jak to obrazowo określono - „uprzemysłowienie wykształconych warstw narodu". Konieczność w tym zakresie uzasadniano w następujący sposób:

Czasy wyłącznego oddawania się zawodom wyzwolonym, opartym na wykształceniu klasycznem i literackiem, minęly dla nas bezpowrotnie. Zjednoczony naród polski innej także od swoich synów wymagać będzie służby ${ }^{30}$.

Rozwijając szczegółowo tę wypowiedź, postulowano trzy poziomy edukacji technicznej ${ }^{31}$, z których każdy odpowiadałby rodzajowi obowiązków $\mathrm{w}$ pracowniczej hierarchii fabrycznej. Trzyletnie niższe szkoły zawodowe przeznaczano dla uczniów, którzy w wieku 13-15 lat ukończyli szkołę ludową. Ich zadaniem miało być przygotowanie profesjonalne robotników, legitymujących się nie tylko gruntowną znajomością swojego fachu, ale również posiadających wiedzę ogólną, która rozwija horyzonty myślowe i ułatwia funkcjonowanie $\mathrm{w}$ zmieniającym się cywilizacyjnie społeczeństwie. Jako wzór tego typu instytucji edukacyjnej przedłożono koncepcję szkoły dla elektromechaników, wyposażającej uczniów w wiadomości i umiejętności naprawiania maszyn i przyrządów elektrycznych, a także wyrabiania prostszych aparatów. Z zamieszczonego planu nauczania wynika, że na blok przedmiotów ogólnych, z przyporządkowaną im tygodniową liczbą godzin w poszczególnych klasach, przewidziano: religię (2 godz. - kl. I i 1 godz. - kl. II), język polski (4 godz. - kl. I, 3 godz. - kl. II i 1 godz. - kl. III), arytmetykę i algebrę (4 godz. - kl. I, 3 godz. - kl. II i 1 godz. - kl. III), geometrię (3 godz. - kl. II i 1 godz. - kl. III) , krajoznawstwo (1 godz. - kl. I), historia Polski (1 godz. - kl. I), fizyka i chemia (2 godz. - kl. I i 2 godz. - kl. II), natomiast na blok przedmio-

${ }^{29}$ Analizując warunki, od których zależy rozwój przemysłowy, W. Chrzanowski przekonywał, że ważną rolę w tym procesie odgrywa upowszechnienie - jak to nazwał - „możliwie największej oświaty wśród sfer pracujących w przemyśle”. Uświadamiał, że co prawda utrzymanie szkolnictwa na wysokim poziomie generuje ogromne wydatki, jednak o ich zasadności przekonuje fakt, że nakłady w tym zakresie zwracają się w przyszłości dzięki dynamicznemu wzrostowi produktu krajowego brutto. Tak pisał na ten temat: „Oświata bowiem przyczynia się znacznie do podniesienia wytwórczości narodowej, a tem samem do podniesienia możności płacenia podatków, nie mówiąc już o stronie moralnej". W. Chrzanowski, Czynniki warunkujące rozwój naszego przemystu, „Przegląd Techniczny” 1919, nr 49-52, s. 181.

${ }^{30}$ S. Kossuth, Potrzeba uprzemystowienia kraju i ogólne widoki rozwoju przemystu na ziemiach polskich. Włókiennictwo, „Przegląd Techniczny” 1915, nr 29-30, s. 301.

${ }^{31}$ Również na łamach innych czasopism adresowanych do inteligencji technicznej rozważano o potrzebie zmiany nastawienia przez społeczeństwo do kształcenia w szkołach zawodowych, dowodząc, że kształcenie profesjonalne młodzieży „może być skuteczną dźwignią rozwoju narodowego". Zob. np. D. Krzyczkowski, Szkoły przemystowe. Szkic Organizacyi Zarządu szkolnictwa przemystowego w przeszłem państwie polskiem, "Czasopismo Techniczne” 1918, nr 10, s. 87. 
tów zawodowych, także z przyporządkowaną im tygodniową liczbą godzin w poszczególnych klasach, zaplanowano: maszynoznawstwo (2 godz. - kl. III), kreślarstwo (2 godz. - kl. I), rysunki techniczne (2 godz. - kl. I, 2 godz. - kl. II, 4 godz. - kl. III), towaroznawstwo (2 godz. - kl. III), zasadnicze pojęcia z elektrotechniki (4 godz. - kl. II), elektrotechnikę stosowaną (7 godz. - kl. III), ćwiczenia w pracowni elektrotechnicznej (6 godz. - kl. III), pracę w warsztatach (30 godz. - kl. I, 30 godz. - kl. II, 30 godz. - kl. III). Po wyliczeniu wszystkich przedmiotów nauczania, przybliżono także, jakie dokładnie treści zostały do nich przypisane. Na uwagę zasługują w tym przypadku zagadnienia przeznaczone do realizacji na zajęciach języka polskiego, ponieważ zdefiniowano je wyłącznie w kategoriach praktycznej użyteczności. Pierwszy rok nauki stanowił nawiązanie do kwestii omawianych już w szkole ludowej i obejmował różnorakie ćwiczenia z ortografii, natomiast w kolejnych dwóch latach miano nauczać między innymi pisania listów handlowych, redagowania ofert oraz zamówień towarowych, a także wypełniania szeregu urzędowych druków: blankietów i formularzy ${ }^{32}$.

Nie akceptując poglądów części inteligencji, która reprezentowała stanowisko, że w odbudowywanym niepodległym państwie należy zrezygnować z funkcjonowania średnich szkół zawodowych, w czasopiśmie twierdzono, że organizacja nowoczesnej produkcji przemysłowej wymaga kadr tak zwanego operacyjnego poziomu zarządzania, które byłyby szerzej wykształcone niż robotnicy, ale nie dorównywałyby rozległością naukowego przygotowania osobom $z$ dyplomem inżyniera ${ }^{33}$. Tak pisano na ten temat:

Stanowiska (...) majstrów czy zawiadowców fabryk mają taki specyficzny charakter, wymagają często tak dużej ilości wiadomości fachowych, rutyny i pewności w załatwianiu wielu spraw, że z konieczności bardziej teoretycznie wykształcony młody inżynier sprostać im nie może, co szkodliwie się znów odbija na biegu życia fabrycznego. Więc za niewłaściwe uważać należy powyższe stanowiska jako przejściowe, jako etap do zajmowania stanowisk kierowniczych dla inżynierów, przeciwnie, należy powierzać je technikom o wykształceniu średnim, technikom, którzy traktować je będą jako swe zajęcie stałe ${ }^{34}$.

Dostrzegając niezastąpioną rolę techników w przebiegu procesów wytwarzania dóbr, wyjaśniano, że powinni oni posiadać umiejętności posługiwania się maszynami fabrycznymi, potrafić zorganizować warsztat pra-

32 J. Tymowski, Niższe szkolnictwo, s. 305.

${ }^{33}$ W. Chromiński, Nadzwyczajny Zjazd Techników Polskich w Warszawie, PT, 1917, nr 19-20, s. 143-144; S. Patschke, Szkoty techniczne wyższe w związku z przygotowaniem techników przemystowych, [w:] Pamiętnik Nadzwyczajnego Zjazdu Techników Polskich w Warszawie w roku 1917, red. W. Chromiński, Warszawa 1917, s. 85-87.

${ }^{34}$ M. Sikorski, Średnie szkolnictwo elektrotechniczne, „Przegląd Techniczny” 1917, nr 3132, s. 269. 
cy, orientować się we wszystkich praktycznych sposobach wykonywania przedmiotów, doskonale znać się na właściwościach różnorodnych materiałów, a także wykazywać otwartością wobec wynalazków technologicznych oraz charakteryzować się zdolnościami przekonywania podwładnych do stosowania innowacyjnych metod pracy. Opowiadając się za koncepcją utylitaryzmu dydaktycznego, propagowano projekt średniej szkoły kształcącej „inteligentnych techników, przystosowanych do potrzeb przemysłu”. Dlatego nie koncentrowano się na rodzajach wykładanych przedmiotów, lecz zwracano uwagę na konieczność zatrudniania w niej na stanowiskach nauczycieli wyłącznie inżynierów praktyków, którzy niezależnie od przekazywania uczniom wiadomości teoretycznych, położyliby przede wszystkim nacisk na ich praktyczne zastosowanie. Tłumaczono, że realizowane $\mathrm{w}$ ten sposób zajęcia audytoryjne i w warsztatach szkolnych oraz przeprowadzany metodycznie instruktaż przygotowujący uczniów do zapoznawania się w okresie wakacyjnym z konkretnymi stanowiskami pracy w fabrykach stanowią najważniejszą część składową edukacji w średnich szkołach o profilu technicznym ${ }^{35}$.

Największe zainteresowanie redaktorów "Przeglądu Technicznego" wzbudzał problem kształcenia technicznego na poziomie wyższym, które postrzegano jako najważniejszy czynnik przyczyniający się do uprzemysłowienia odrodzonego państwa polskiego. Ponieważ z powodów politycznych nie funkcjonowała w Warszawie wyższa szkoła techniczna, zachęcano do podnoszenia kwalifikacji zawodowych na Wydziale Technicznym Towarzystwa Kursów Naukowych, na którym organizowano wzorowane na programach politechnik angielskich i amerykańskich wykłady z rozmaitych działów techniki, między innymi mechaniki, elektrotechniki, konstrukcji budowlanych, hydrauliki oraz urządzeń sanitarnych ${ }^{36}$.

Zastanawiając się nad modelem wyższego szkolnictwa politechnicznego, z jednej strony rozważano na szpaltach „Przeglądu Technicznego” o obszarach i zakresie wiedzy oraz umiejętnościach fachowych inżyniera ${ }^{37}$, odwo-

35 Tamże.

36 Zob. np. Wykłady z techniki sanitarnej, "Przegląd Techniczny” 1915, nr 17-18, s. 174; Kurs techniki sanitarnej, "Przegląd Techniczny” 1915, nr 33-34, s. 338; Kursy wieczorowe dla techników, „Przegląd Techniczny” 1916, nr 37-38, s. 368; Program wykładów wieczornych dla techników na rok 1916/17 w Tow. Kursów Naukowych w Warszawie, "Przegląd Techniczny” 1916, nr 39-40, s. 390; Program wykładów wieczornych dla techników na rok 1916/17 w Tow. Kursów Naukowych w Warszawie, "Przegląd Techniczny" 1916, nr 47-48, s. 453-454. Zob. też: Dziesięciolecie Wolnej Wszechnicy Polskiej. TKN: Sprawozdanie z działalności Towarzystwa Kursów Naukowych 1906-1916, red. S. Orłowski, Warszawa 1917, s. 22, 24-25, 27-28, 103-110.

37 W. Chrzanowski, Luźne uwagi o wykształceniu inżyniera mechanika, "Przegląd Techniczny" 1914, nr 18, s. 236-239; J. Kłos, O wykształceniu i egzaminach architekta, "Przegląd Techniczny" 1916, nr 15-16, s. 153-156; nr 23-24, s. 258-259; F. Kucharzewski, Wykształcenie matematyczne inżynierów, „Przegląd Techniczny” 1915, nr 19-20, s. 187-189; nr 23-24, s. 245-247. 
ływano się do organizacji kształcenia i prac badawczych zapisanych w projekcie z 1828 roku Instytutu Politechnicznego w Warszawie ${ }^{38}$, przypominano funkcjonowanie w latach 1862-1869 Instytutu Politechnicznego i RolniczoLeśnego w Puławach, przedstawiano dorobek jedynej wówczas polskiej wyższej szkoły technicznej - Politechniki Lwowskiej ${ }^{39}$, z drugiej natomiast przybliżano działalność uczelni tego typu w Niemczech, Austrii, Francji oraz w Stanach Zjednoczonych ${ }^{40}$.

Kiedy po długich zmaganiach działaczy społecznych i oświatowych ${ }^{41}$ otwarto w Warszawie w 1915 roku Politechnikę, redakcja czasopisma poświęciła temu wydarzeniu obszerny artykuł, w którym w szczegółach opisano genezę tego przedsięwzięcia, przedstawiono w tabelach wykazy obowiązkowych przedmiotów kształcenia na tymczasowo powołanych fakultetach: inżynierii budowlanej i inżynierii rolnej, budowy maszyn i elektrotechniki, chemicznym i architektonicznym, zamieszczono tymczasowy statut uczelni, zaprezentowano sylwetkę rektora - Zygmunta Straszewicza i dziekanów poszczególnych wydziałów: Henryka Czopowskiego, Stanisława Patschke, Tadeusza Miłobęckiego i Józefa Dziekońskiego oraz przybliżono biogramy docentów, którym powierzono wykłady ze wszystkich przedmiotów składających się na tymczasowy program czteroletnich studiów inżynierskich ${ }^{42}$.

Zapoznając z przebiegiem obchodów otwarcia Politechniki Warszawskiej, informowano, że rozpoczęła je Msza św. w Archikatedrze św. Jana Chrzciciela celebrowana przez metropolitę warszawskiego ks. arcybiskupa Aleksandra Kakowskiego, podczas której ks. kanonik Antoni Szlagowski wygłosił - jak to określono - „świetną i wzruszającą mowę", kierując do wiernych między innymi słowa:

${ }^{38}$ Na temat tego projektu można przeczytać w: J. Miąso, Szkolnictwo zawodowe w Królestwie Polskim, s. 48-51.

${ }^{39}$ F. K., Politechniki niemieckie i polskie przed r. 1900, "Przegląd Techniczny” 1915, nr 9-10, s. 80; J. Dmochowski, Warstwy społeczne wobec przemystu, PT, 1915, nr 51-52, s. 486-488; F. Kucharzewski, Szkoła Politechniczna Lwowska, „Przegląd Techniczny” 1915, nr 1-2, s. 1-5; tenże, Politechniki polskie wśród rozwoju tych szkót na zachodzie, „Przegląd Techniczny” 1916, nr 19-20, s. 184-185.

${ }^{40}$ F. K., Politechniki niemieckie i polskie, s. 79-80; F. Kucharzewski, Politechniki polskie, s. 184190; W. Bryła, Wyższe szkolnictwo techniczne w Ameryce Pótnocnej, „Przegląd Techniczny” 1915, nr 33-34, s. 335-336; nr 35-36, s. 350-352; nr 41-42, s. 400-402; nr 45-46, s. 434-436.

${ }^{41}$ Starania o utworzenie w Warszawie polskiej Politechniki podjęli twórcy Towarzystwa Kursów Naukowych już w 1906 r., jednak nie uzyskały one żadnego poparcia władz carskich. Sytuacja w tym zakresie diametralnie zmieniła się po wybuchu pierwszej wojny światowej i ustąpieniu Rosjan z Warszawy w 1915 r. Ponieważ niemiecki rząd okupacyjny okazał się bardziej przychylny wobec otwarcia w Warszawie polskich szkół wyższych, powołana w grudniu 1914 r. Komisja Politechniczna TKN zainicjowała prace nad koncepcją organizacji i programu przyszłej Politechniki. Zob. Dziesięciolecie Wolnej Wszechnicy Polskiej. TKN: Sprawozdanie z działalności Towarzystwa Kursów Naukowych 1906-1916, red. S. Orłowski, Warszawa 1917, s. 2834, 116-119.

${ }^{42}$ P. T., Otwarcie Politechniki w Warszazie, „Przegląd Techniczny” 1915, nr 49-50, s. 559-467. 
Zmartwychwstał Chrystus, gdy wzeszło słońce, zmartwychwstanie Polska, gdy jasna światłość oświaty i wiedzy wejdzie nad krajem i urośnie aż do dnia doskonałego. Noc przeminęła, dzień się przybliżył, jutrzenka już zaświtała w onem prawie o powszechnem nauczaniu, co zbliża nas i wiąże z Komisyą Edukacyjną, pierwszym w Europie wydziałem oświecenia. (...) Dziś wracamy do swego. Dziś w salach, gdzie mowa Polska milczała, myśl Polska odezwie się po raz pierwszy po latach melodyą Polskiego słowa. O czem w gorących pragnieniach marzyliśmy, do czego bezsprzecznie wciąż rościmy sobie prawa, a co niezniszczalnem się niedawno jeszcze wydawało, to iści się przed oczyma naszemi. Oto polska Wszechnica ${ }^{43}$.

Zdając natomiast sprawozdanie z ceremonii inauguracji pierwszego roku akademickiego, która odbyła się już w gmachu Politechniki, relacjonowano, że rektor na wstępie swojego przemówienia skoncentrował się na emocjonalnym uświadamianiu zgromadzonych o wyjątkowości tego wydarzenia w dziejach narodu polskiego, a następnie - zwrócił się do generała-gubernatora warszawskiego - Hansa Hartwiga von Beselera, dziękując mu za przychylność i pomoc administracyjną w powołaniu uczelni technicznej w Warszawie. W dalszej kolejności wyjaśnił immatrykulowanej młodzieży, jakie są jej prawa i obowiązki oraz obwieścił, że przyjmują na siebie obowiązek pielęgnowania najlepszych tradycji akademickich. Tak na ten temat apelował do studentów:

Przez długi szereg lat niewoli dobiegają do nas echa akademickich tradycyi Krzemieńca, Wilna i warszawskiej Szkoły Głównej. Wsłuchajmy się pilnie w te echa i starajmy się wszyscy, aby powstająca dziś szkoła nie sprzeniewierzyła się tym tradycyom, i aby tradycye, które my nawiążemy i które po nas zostaną, były rozumne i szlachetne, bo spadł na nas wszystkich wielki honor: na was, że będziecie pierwszymi słuchaczami, na nas, że będziemy pierwszymi wykładającymi w tej nowej szkole polskiej, ale jednocześnie spadła na nas ciężka odpowiedzialność przed krajem i jego przyszłością ${ }^{44}$.

Warto podkreślić, że reporterzy „Przeglądu Technicznego” zamieścili w sprawozdaniu z uroczystości inauguracji pierwszego roku akademickiego na Politechnice Warszawskiej treść odczytanych przez rektora niektórych listów gratulacyjnych, nadesłanych z okazji otwarcia tej uczelni. Wśród nadawców znalazły się miedzy innymi takie placówki naukowe oraz stowarzyszenia zawodowe, jak: Akademia Umiejętności w Krakowie, Senat Akademicki Uniwersytetu Jagiellońskiego, Rektor C.K. Szkoły Politechnicznej we Lwowie, Towarzystwo Politechniczne we Lwowie, Stowarzyszenie Techników w Łodzi, Stowarzyszenie Techników w Warszawie oraz Towarzystwo Przemysłowców Królestwa Polskiego ${ }^{45}$. Życząc kadrze naukowej i młodzieży akademickiej owocnej pracy dla dobra polskiej nauki i polskiej kultury, dzia-

\footnotetext{
43 Tamże, s. 467.

${ }^{44}$ Tamże, s. 468.

${ }^{45}$ Tamże.
} 
łacze wpływowego wówczas związku fabrykantów w podniosłej formie napisali:

Towarzystwo Przemysłowców wyraża swe głębokie przekonanie, że polska Politechnika Warszawska, powstająca w chwili, gdy wstrząśnięte są podwaliny życia gospodarczego Ojczyzny naszej, gdy nasze fabryki i warsztaty pracy jedne leżą w ruinie, inne zamarły w bezruchu, nie tylko stanie się dźwignią wznowienia twórczej współpracy przemysłowca i robotnika polskiego, lecz nowe życie przemysłowe rozkrzewi na ziemiach naszych, zasili je zastępem sił młodych i dzielnych, które ugruntują przemysł rodzimy i podniosą go na należne mu wyżyny ${ }^{46}$.

Podsumowując, należy stwierdzić, że po wybuchu pierwszej wojny światowej w środowisku techników warszawskich dominowało przekonanie o rychłym odzyskaniu przez Polskę niepodległości. Prowadząc na łamach „Przeglądu Technicznego" rozległą debatę o perspektywach odbudowy przyszłego państwa, nie tylko nakreślano własną wizję rozwoju poszczególnych gałęzi przemysłu ${ }^{47}$, ale dawano także wyraz konieczności zmiany stosunku społeczeństwa do edukacji techniczno-ekonomicznej oraz podkreślano potrzebę modernizacji szkolnictwa zawodowego na wszystkich poziomach i unowocześnienia form doskonalenia profesjonalnego, upatrując w tych działaniach zasadniczy warunek nowoczesnej i wszechstronnej industrializacji kraju.

\section{BIBLIOGRAFIA}

\section{Źródła}

Bryła W., Wyższe szkolnictwo techniczne w Ameryce Pótnocnej, „Przegląd Techniczny” 1915, nr 33-34; nr 35-36; nr 41-42; nr 45-46.

Chromiński W., Nadzwyczajny Zjazd Techników Polskich w Warszawie, PT, 1917, nr 19-20.

Chrzanowski W., Luźne uwagi o wykształceniu inżyniera mechanika, "Przegląd Techniczny” 1914, nr 18.

Chrzanowski W., Czynniki warunkujące rozwój naszego przemystu, „Przegląd Techniczny” 1919, nr 49-52.

Dmochowski J., Warstwy społeczne wobec przemystu, PT, 1915, nr 51-52.

F. K., Politechniki niemieckie i polskie przed r. 1900, „Przegląd Techniczny” 1915, nr 9-10.

J. T-i, Kursa wieczorowe dla elektromonterów przy Muzeum Przemystu i rolnictwa, „Przegląd Techniczny" 1916, nr 47 i 48.

J. T-i, Kursa przygotowawcze dla elektromonterów przy Muzeum Przemystu i Rolnictwa, „Przegląd Techniczny" 1917, nr 43 i 44.

Kłos J., O wykształceniu i egzaminach architekta, „Przegląd Techniczny” 1916, nr 15-16.

46 Tamże.

47 Por. J. Piłatowicz, Rola "Przeglądu Technicznego" w kształtowaniu poglądów środowiska technicznego w przełomowych okresach dziejów Polski, Rocznik I Polskiego Towarzystwa Historii Techniki, 1983-1998, s. 129. 
K. M., Popularyzacya wiedzy elektrotechnicznej. Odczyty popularne w Warszawie, "Przegląd Techniczny" 1916, nr 17 i 18.

Kossuth S., Potrzeba uprzemystowienia kraju i ogólne widoki rozwoju przemystu na ziemiach polskich. Wtókiennictwo, „Przegląd Techniczny” 1915, nr 29-30.

Kucharzewski F., Szkoła Politechniczna Lwowska, „Przegląd Techniczny” 1915, nr 1-2.

Kucharzewski F., Wyksztatcenie matematyczne inżynierów, „Przegląd Techniczny” 1915, nr 19-20.

Kucharzewski F., Politechniki polskie wśród rozwoju tych szkół na zachodzie, „Przegląd Techniczny" 1916, nr 19-20.

Krzyczkowski D., Szkoły przemysłowe. Szkic Organizacyi Zarządu szkolnictwa przemysłowego w przeszłem państwie polskiem, "Czasopismo Techniczne” 1918, nr 10.

Kurs techniki sanitarnej, „Przegląd Techniczny” 1915, nr 33-34.

Kursa dla monterów elektrotechników w Sosnowcu, „Przegląd Techniczny” 1916, nr 17 i 18.

Kursa zawodowe dla maszynistów, „Przegląd Techniczny” 1917, nr 47-48.

Kursy wieczorowe dla techników, „Przegląd Techniczny” 1916, nr 37-38.

Orłowski S. (red.), Dziesięciolecie Wolnej Wszechnicy Polskiej. TKN: Sprawozdanie z działalności Towarzystwa Kursów Naukowych 1906-1916, Warszawa 1917.

Patschke S., Szkoły techniczne wyższe w związku z przygotowaniem techników przemystowych, [w:] Pamiętnik Nadzwyczajnego Zjazdu Techników Polskich w Warszawie w roku 1917, red. W. Chromiński, Warszawa 1917.

Potrzeba uprzemystowienia kraju i ogólne widoki rozwoju przemystu na Ziemiach Polskich, „Przegląd Techniczny" 1915, nr 51 i 52.

Program wykładów wieczornych dla techników na rok 1916/17 w Tow. Kursów Naukowych w Warszawie, „Przegląd Techniczny” 1916, nr 39-40.

Program wykładów wieczornych dla techników na rok 1916/17 w Tow. Kursów Naukowych w Warszawie, „Przegląd Techniczny” 1916, nr 47-48.

P. T., Otwarcie Politechniki w Warszawie, „Przegląd Techniczny” 1915, nr 49-50.

Sikorski M., Średnie szkolnictwo elektrotechniczne, „Przegląd Techniczny” 1917, nr 31-32.

Tymowski J., Niższe szkolnictwo elektrotechniczne, „Przegląd Techniczny” 1917, nr 35 i 36.

Twardo S., Organizacya niższego szkolnictwa zawodowego w Królestwie Polskim w chwili odbudowy kraju i państwa, [w:] Pamiętnik Nadzwyczajnego Zjazdu Techników w Warszawie w roku 1917, red. W. Chromiński, Warszawa 1917.

Wykłady z techniki sanitarnej, „Przegląd Techniczny” 1915, nr 17-18.

Ze Szkoty Mechaniczno-Technicznej Wawelberga i Rotwanda, "Przegląd Techniczny" 1914, nr 31.

Ze Szkoły Mechaniczno-Technicznej Wawelberga i Rotwanda, "Przegląd Techniczny” 1916, nr 7-8.

\section{Opracowania}

Araszkiewicz F.W., Szkoła średnia ogólnoksztatcaca na ziemiach polskich w latach 1915-1918, Rozprawy z Dziejów Oświaty, 1967, 10.

Chwalba A., Samobójstwo Europy. Wielka Wojna 1914-1918, Kraków 2014.

Filipowicz F., Narodziny ruchu, [w:] Związek Nauczycielstwa Polskiego. Zarys dziejów 19051985, red. B. Grześ, Warszawa 1986.

Korzeniowski M., Wojna na Lubelszczyźnie w latach 1914-1915 w świetle wspomnień, Przegląd Wschodnioeuropejski, 2017, VIII, 2.

Kubiatowski J. (oprac.), Sylwetki profesorów Politechniki Warszawskiej. Leon Karasiński (18791945), http:/ / bcpw.bg.pw.edu.pl/Content/842/sylw_prof_027.pdf 
Mańkiewicz-Cudny E., 140 lat „Przegladu Technicznego, Rocznik PTHT, 2006.

Miąso J., Szkolnictwo zawodowe w Królestwie Polskim w latach 1815-1915, Wrocław - Warszawa - Kraków 1966.

Piłatowicz J., Polskie czasopisma ogólnotechniczne przed $i$ w okresie I wojny światowej, Kwartalnik Historii Prasy Polskiej, 1990, 29, 3-4.

Piłatowicz J., Rola „Przeglądu Technicznego" w ksztattowaniu pogląów środowiska technicznego w przełomowych okresach dziejów Polski, Rocznik I Polskiego Towarzystwa Historii Techniki, 1983-1998.

Sosnowski P., Dzieje Stowarzyszenia Nauczycielstwa Polskiego (1905-1919), Warszawa 1930.

Sroka S.T., Śliwiński Stanistaw (1875-1950), [w:] Polski Stownik Biograficzny, t. 50/4, Warszawa - Kraków 2016.

Szulkin M., Polski Związek Nauczycielski (1905-1917). Studium z dziejów postępowego ruchu nauczycielskiego w Polsce, Warszawa 1968.

Uzarowicz L., Szkoła Wawelberga i Rotwanda, [w:] Politechnika Warszawska 1915-1965, Warszawa 1965.

Wroczyński R., Dzieje oświaty polskiej 1795-1945, Warszawa 1987. 